\title{
Penguatan Kapasitas Desa Binaan Melalui Program Laboratorium Desa Di Kecamatan Kamal, Kabupaten Bangkalan
}

\author{
Mohtar Rasyid \\ Universitas Trunojoyo Madura \\ mohtar.rasyid@trunojoyo.ac.id
}

\begin{abstract}
Some villages in the Kamal, Bangkalan-Madura, have so far been classified as underdeveloped, even though they are quite close to the Universitas Trunojoyo Madura. To that end, the Faculty of Economics and Business, Universitas Trunojoyo Madura took the initiative to implement the Village Laboratory Program with the aim of increasing the capacity of village officials in carrying out activities that had been carried out so far. This activity is integrated with the existing curriculum in the Department of Economics so that for each class it is expected to be able to assist one fostered village. In the first stage, four villages in SubDistrict Kamal were selected, each coordinated by one supervisor. Students are expected to work with the village community to solve the problems that exist in each village. The allocation of mentoring time is one semester and can be continued if it is deemed necessary to be extended. So far, these activities have helped many local village programs ranging from structuring village governance administration, village initiatives in preparing strategic plans and increasing village creativity in serving the local community.
\end{abstract}

Keywords: Laboratory; Fostered Village; Society service

\begin{abstract}
Abstrak
Beberapa desa di Kecamatan Kamal Bangkalan, selama ini masih termasuk sebagai desa yang kurang berkembang meskipun letaknya cukup dekat dengan Kampus Universitas Trunojoyo Madura. Untuk itu, Fakultas Ekonomi dan Bisnis Universitas Trunojoyo Madura berinisiatif melaksanakan Program Laboratorium Desa dengan tujuan untuk meningkatkan kapasitas aparat desa dalam melaksanakan kegiatan yang selama ini telah dilakukan. Kegiatan ini diintegrasikan dengan kurikulum yang ada di Jurusan Ilmu Ekonomi sehingga untuk setiap kelas diharapkan dapat mendampingi satu desa binaan. Dalam tahap pertama, terpilih empat desa di Kecamatan Kamal dengan masing-masing dikoordinasi oleh satu dosen pembimbing. Mahasiswa diharapkan dapat bekerja bersama masyarakat desa untuk memecahkan permasalahan yang ada di tiap-tiap desa. Alokasi waktu pendampingan adalah sebanyak satu semester dan bisa dilanjutkan jika dirasa masih perlu untuk diperpanjang. Sejauh ini kegiatan tersebut telah banyak membantu program desa setempat mulai dari penataan administrasi tata kelola desa, inisiatif desa dalam penyusunan rencana strategis serta meningkatkan kreativitas desa dalam melayani masyarakat setempat.
\end{abstract}

Kata Kunci: Laboratorium; Desa Binaan; Pelayanan Masyarakat 


\section{Pendahuluan}

Sasaran utama pembangunan di Indonesia adalah masyarakat pedesaan karena sebagian besar penduduk Indonesia tinggal di pedesaan. Hal inilah yang membuat pemerintah melalui Program Nawacita salah satunya adalah membangun Indonesia dari pinggiran dengan cara memperkuat daerah-daerah dan desa. Desa menjadi basis utama bagi pembangunan bangsa, pengembangan desa sebagai penyedia tenaga kerja untuk pengelolaan desa itu sendiri, dan juga untuk sektor perkotaan. Penguatan desa untuk tumbuh berkembang secara modern tanpa menghilangkan ciri / karakteristik desa serta budaya. Modernisasi desa dapat menjadi katalis untuk pengembangan pendidikan, kesehatan, wirausaha desa, penyediaan air bersih, sanitasi, keberlanjutan lingkungan dan partisipasi demokratis yang akan mendukung perbaikan lebih lanjut.

Adapun hakikat pembangunan desa itu sendiri adalah keseluruhan kegiatan yang berlangsung di pedesaan dan meliputi seluruh aspek kehidupan masyarakat yang dilaksanakan dengan mengembangkan semangat gotong royong. Dengan demikian jelaslah bahwa pembangunan desa membutuhkan keterlibatan dan peran aktif seluruh masyarakat, aparat desa dan berbagai pihak. Meskipun demikian, pembangunan desa masih memiliki berbagai permasalahan, seperti adanya desa terpencil atau terisolir dari pusat-pusat pembangunan. Masih minimnya prasarana sosial ekonomi serta penyebaran jumlah tenaga kerja produktif yang tidak seimbang.

Fakta menunjukkan bahwa masih banyak desa di Indonesia yang hidup di bawah garis kemiskinan. Perkembangan wilayah sekitar tidak secara otomatis menjamin peningkatan desa tertinggal. Dengan kata lain, efek menetes ke bawah dari sebuah pembangunan tidak dapat diperoleh secara cuma-cuma, namun melalui pola perencanaan dan pelaksanaan aktivitas yang efektif. (Suripan, Sucipto, Nurhadi, \& Sopingi, 2017)

Salah satu daerah yang memiliki daerah atau desa tertinggal cukup banyak adalah Jawa Timur, lebih khususnya di daerah Madura. Data menunjukkan bahwa dua Kabupaten di Madura masih tergolong sebagai daerah dengan Indeks Pembangunan Manusia (IPM) yang rendah; yakni Kabupaten Sampang dan Kabupaten Bangkalan.

Kabupaten Bangkalan sebenarnya memiliki potensi besar untuk berkembang. Pertama, daerah tersebut terhubung langsung dengan pusat pertumbuhan ekonomi di Indonesia Timur melalui Jembatan Suramadu. Kedua, memiliki potensi alam yang bisa dikembangkan untuk pengembangan industri, baik industri pengolahan maupun pariwisata. Ketiga, memiliki potensi sumber daya manusia yang cukup baik, seiring dengan berdirinya Universitas Trunojoyo Madura (UTM) yang terletak di Kecamatan Kamal.

Berdirinya kampus di sekitar daerah yang masih tertinggal tidak menjamin akan menyebabkan peningkatan ekonomi signifikan. Untuk itu diperlukan berbagai pendekatan untuk mengembangkan daerah sekitar kampus, baik secara top-down maupun botton-up. Pendekatan tersebut dipilih dan diaplikasikan untuk membantu masyarakat sekitar kampus agar dapat bersinergi guna meningkatkan potensi desa secara optimal. Terkait dengan hal tersebut, Jurusan Ilmu Ekonomi, Fakultas Ekonomi dan Bisnis UTM menginisiasi terbentuknya Laboratorium Desa sebagai bentuk nyata pelaksanaan Tri Dharma Perguruan Tinggi dalam bentuk kegiatan Pengabdian Kepada Masyarakat.

Model laboratorium desa telah banyak diadopsi oleh berbagai instansi baik secara generik maupun dengan pelaksanaan kegiatan yang spesifik (Sukayadi, Indradi, Wiyono, Subroto, \& Nugroho, 2013). Fakultas Ekonomi dan Bisnis UTM cenderung menggunakan pendekatan partisipatif agar proses pembentukan laboratorium desa berjalan secara alamiah 
tanpa kesan menggurui karena sejatinya yang mengerti kondisi, potensi, permasalahan dan penyelesaian masalah desa adalah masyarakat desa itu sendiri. Kampus dalam hal ini lebih berperan sebagai pendamping dalam mewujudkan sasaran pembangunan yang telah ditetapkan oleh masyarakat setempat.

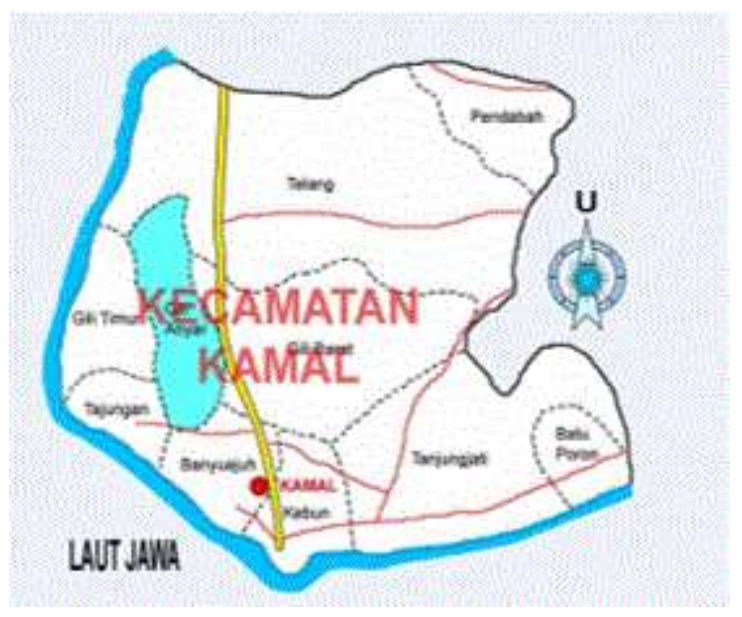

Gambar 1. Peta Kecamatan Kamal

Gambar 1 menunjukkan peta Kecamatan Kamal, Kabupaten Bangkalan yang berbatasan dengan Laut Jawa dan Selat Madura. Sebelum adanya Jembatan Suramadu, akses jalan Bangkalan-Kamal merupakan satu-satunya pintu gerbang menuju dan balik dari Madura-Jawa. Selat Madura kala itu hanya terbubung oleh angkutan feri yang disediakan oleh ASDP. Selat Madura merupakan arus lalu lintas paling padat karena tingkat mobilitas masyarakat Madura yang memang terkenal cukup tinggi. Daerah Pelabuhan Kamal dan sekitarnya menjadi daerah dengan tingkat aktivitas ekonomi yang cukup padat.

Saat ini, era keemasan feri Surabaya-Madura sudah berakhir setelah jembatan penghubung Surabaya Madura berdiri dan diresmikan. Titik pertumbuhan ekonomi di Ujung Kamal, lambat laun bergeser agak ke timur mengikuti kontur Jembatan Suramadu. Akibatnya, daerah atau desa yang sebelumnya tergantung pada limpahan ekonomi pelabuhan Selat Madura, harus menemukan sumber ekonomi baru yang bisa menopang kehidupan masyarakat setempat.

Jembatan Suramadu sebenarnya membuka peluang bagi masyarakat Madura untuk lebih sejahtera. Namun, tentu saja dibutuhkan waktu adaptasi dari yang sebelumnya hanya mengandalkan rezeki dari feri, bergeser pada optimalisasi potensi Jembatan Suramadu sebagai jalan raya perputaran ekonomi dari Jawa menuju Madura.

Proses adaptasi ini tentu saja tidak mudah. Terutama bagi desa yang potensi ekonominya hanya mengandalkan sektor pertanian konvensional. Keberadaan kampus sebenarnya dapat menjadi salah satu sumber ekonomi baru bagi desa setempat. Sejumlah contoh dapat dijadikan sebagai referensi, misalnya Kampus Universitas Airlangga Surabaya yang berkontribusi terhadap perkembangan daerah Surabaya Timur atau Kampus UGM yang berkontribusi terhadap perekonomian masyarakat Sleman dan sekitarnya.

Kontribusi pemikiran Jurusan Ilmu Ekonomi Fakultas Ekonomi dan Bisnis UTM dalam upaya membangun desa tertinggal di Wilayah Kabupaten Bangkalan yaitu berupa konsep Pembangunan Desa Mandiri. Konsep detail Pembangunan Desa Mandiri akan disusun dalam sebuah dokumen rencana Masterplan Pembangunan Desa Mandiri. Maksud dari penyusunan Masterplan Pembangunan Desa Mandiri (MPDM) adalah untuk mengkaji pendekatan secara keseluruhan yang berkaitan dengan pelaksanaan gagasan, perencanaan, dan implementasi sebuah aktivitas dalam pengembangan desa berdasarkan ragam potensi yang ada di setiap desa. Masterplan Pembangunan Desa Mandiri (MPDM) mempunyai karakter dan ciri khusus yang aplikatif terhadap pembangunan desa berlandaskan ekonomi pancasila dalam perspektif Ekonomi Kerakyatan, sehingga tidak hanya menghasilkan desa yang mandiri tapi juga masyarakat yang mandiri seperti masyarakat yang dibangun berdasarakan kemandirian bangsa (Samidjo, 2016). 


\section{Pelaksanaan Dan Metode}

Pelaksanaan program penguatan kapasitas desa binaan melalui pembentukan laboratorium secara ringkas dapat dijelaskan melalui serangkaian kegiatan sebagai berikut:

\section{Focus Group Discussion (FGD)}

Kegiatan ini merupakan langkah awal yang dilakukan untuk merumuskan konsep yang berkaitan dengan laboratorium desa. Pada tahap ini juga diidentifikasi desa mana saja yang akan dijadikan sebagai desa "treatment" dalam laboratorium yang akan di bentuk. Pihak yang berkepentingan dengan terbentuknya laboratorium diundang untuk memberikan masukan.

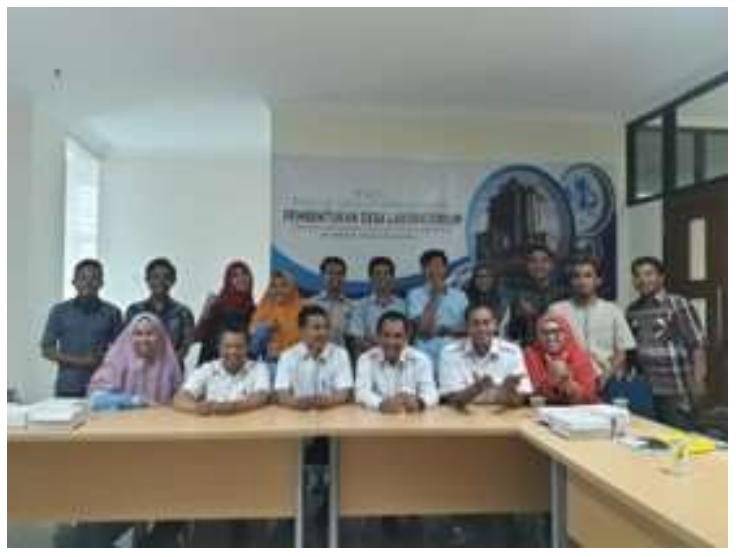

Gambar 2. FDG dengan stakeholder

Turut diundang dalam kegiatan ini adalah Camat Kamal, Bangkalan; Kepada Desa di sekitar Kecamatan Kamal; Dosen Pendamping dan Mahasiswa yang akan diterjunkan ke lapangan. Hasil FGD banyak menghasilkan berbagai konsep pengembangan desa seperti diperlukannya pelatihan manajemen SDM (Harmalik, 2001) hingga konsep pemanfaatan potensi sekitar desa atau pekarangan desa (Mulyanto, 2011).

Pelaksanaan FGD dilaksanakan mulai pertengahan tahun 2018 secara berkesinambungan agar tujuan pelaksanaan program dapat dicapai dengan optimal.
Berbagai kendala yang dialami selama proses pembangunan desa juga dikemukakan langsung oleh aparat Kecamatan Kamal maupun aparat desa setempat.

\section{Penandatanganan Kerjasama}

Setelah dilakukan serangkaian FGD, langkah selanjutnya adalah melakukan formalisasi kegiatan yang tertuang dalam naskah kerja sama. Kegiatan ini dilaksanakan pada tanggal 27 November 2018 bersama dengan kegiatan seminar nasional ekonomi pedesaan di FEB UTM. Kerjasama melibatkan pihak Universitas Trunojoyo Madura (yang dalam hal ini dimotori oleh Jurusan Ilmu Ekonomi) dengan aparat desa terkait serta aparat kecamatan yang mengikat kegiatan laboratorium desa dalam kegiatan desa. Bagi Jurusan Ilmu Ekonomi sendiri, kerja sama ini menjadi bagian penting dalam penyusunan kurikulum.

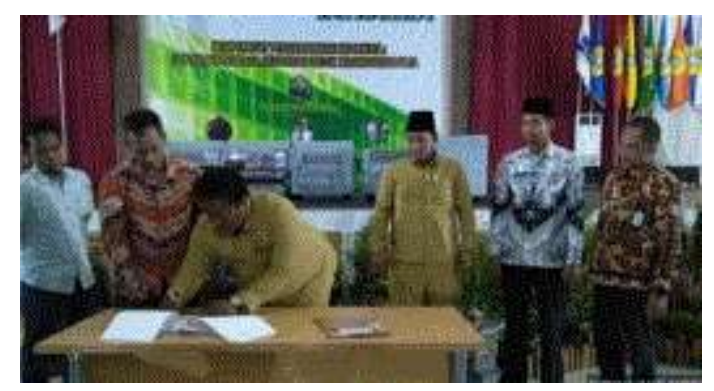

Gambar 3. Kerja Sama

Dalam kegiatan penandatanganan naskah kerja sama antara pihak UTM dengan pihak aparat pemerintah desa setempat ini pula juga disaksikan oleh Staf Khusus Presiden Bidang Ekonomi, Prof. Ahmad Erani Yustika, S.E., M.Sc., Ph.D. yang sekaligus menjadi pemateri dalam Seminar Nasional yang mengangkat tema Memperkuat Perekonomian Indonesia dengan Dukungan Lembaga Keuangan untuk Kemandirian Desa. Apresiasi pemerintah pusat merupakan bentuk dukungan terhadap kegiatan laboratorium desa yang mulai dirintis ini. 


\section{Pelaksanaan Kegiatan}

Pelaksanaan program laboratorium desa dikukuhkan melalui Surat Keputusan Dekan Fakultas Ekonomi dan Bisnis Universitas Trunojoyo Madura Nomor 437/UN46.1.12/2018 terkait dengan kegiatan One Class One Village (OCOV) atau kegiatan satu kelas satu desa.

Kegiatan OCOV ini didasarkan atas jumlah angkatan baru program studi Ekonomi Pembangunan yang menerima sebanyak empat kelas. Sementara itu, desa sekitar kampus yang terpilih dalam kegiatan ini juga ada empat desa; yakni Desa Kamal, Desa Telang, Desa Pandaba dan Desa Gili Anyar.

Untuk masing-masing kelas dan desa binaan, ditunjuk masing-masing dosen pembina yang nantinya bertugas untuk memberikan masukan kegiatan, melakukan supervisi ke desa binaan serta memberikan evaluasi serta penilaian terhadap kegiatan mahasiswa selama kegiatan penguatan potensi desa ini berlangsung. Secara efektif program penguatan desa binaan melalui pembentukan laboratorium ini berjalan mulai semester genap 2018/2019.

\section{Hasil dan Pembahasan}

Pada hakikatnya pembangunan Nasional dilaksanakan dengan tujuan untuk mewujudnya: (a) Masyarakat yang adil dan makmur; (b) Pemerataan kesejahteraan material dan spiritual. Di mana ini semua dilakukan berdasarkan atas filosofi Negara dalam kondisi yang merdeka, berdaulat, bersatu dan berkedaulatan rakyat dalam suasana perikehidupan bangsa dan bernegara yang aman, tentram, tertib dan dinamis serta dalam lingkungan pergaulan dunia yang merdeka, bersahabat tertib dan damai.

Masyarakat adalah suatu sistem, kesatuan manusia yang memiliki suatu interaksi, kebiasaan (adat-istiadat), tata cara hidup bersama yang hidup dengan batasanbatasan (aturan-aturan) dan menganggap diri mereka suatu kesatuan sosial yang bersifat berkelanjutan dan terikat. Karena itulah partisipasi masyarakat sangat mempengaruhi kesuksesan pembangunan desa. Faktor-faktor yang mempengaruhi kesuksesan pembangunan desa adalah:

\section{Partisipasi Masyarakat}

Partisipasi masyarakat adalah keikutsertaan masyarakat dalam proses pengidentifikasian masalah dan potensi yang ada di masyarakat, Pemilihan dan pengambilan keputusan tentang alternatif solusi untuk menangani masalah, Pelaksanaan upaya mengatasi masalah, dan keterlibatan masyarakat dalam proses mengevaluasi perubahan yang terjadi. Partisipasi sesuai dengan Undang Undang No. 25 Tahun 2004 tentang sistem Perencanaan Pembangunan Nasional (sebagai salah satu tujuan SPPN Pasal 2 ayat 4 huruf d) memaknai "Partisipasi masyarakat adalah keikutsertaan masyarakat untuk mengakomodasikan kepentingan mereka dalam proses penyusunan rencana pembangunan".

Berdasarkan pengertian tersebut dapat disimpulkan bahwa partisipasi masyarakat merupakan keterlibatan atau keikutsertaan seseorang masyarakat dalam proses interaksi sosial, Pengidentifikasian masalah dan potensi yang ada di masyarakat dalam situasi tertentu, baik dalam pengambilan keputusan (solusi) menangani masalah, pelaksanaan upaya mengatasi masalah, dan proses keterlibatan masyarakat di dalam mengevaluasi perubahan yang terjadi.

\section{Alokasi Dana Desa}

Kinerja aparatur desa dalam
penyelenggaraan pemerintah desa
didukung oleh beberapa faktor.
Berdasarkan hasil penelitian, faktor
tersebut adalah dukungan dana dari
pemerintah daerah yang diberikan melalui
Alokasi Dana Desa dan kemudian
peralatan kantor yang sudah cukup lengkap.


Bantuan Langsung Alokasi Dana Desa yang selanjutnya disebut ADD adalah dana bantuan langsung yang dialokasikan kepada Pemerintah Desa digunakan untuk meningkatkan pelayanan masyarakat, kelembagaan dan prasarana desa yang diperlukan serta diprioritaskan oleh masyarakat, yang pemanfaatan dan administrasi pengelolaannya di lakukan dan dipertanggung jawabkan oleh Kepala Desa. Bantuan Langsung Alokasi Dana Desa (ADD) dimaksudkan sebagai bantuan stimulan atau dana perangsang untuk mendorong dalam membiayai program pemerintah desa yang ditunjang dengan partisipasi swadaya gotongroyong masyarakat dalam melaksanakan kegiatan pemerintahan dan pemberdayaan.

Pengelolaan Alokasi Dana Desa (ADD) merupakan bagian yang tidak terpisahkan dari pengelolaan keuangan desa. Seluruh kegiatan yang didanai Alokasi Dana Desa direncanakan, dilaksanakan dan dievaluasi secara terbuka dengan melibatkan seluruh unsur masyarakat di desa. Seluruh kegiatan harus dapat dipertanggung jawabkan secara administrasi, teknis dan hukum. Dalam hal ini Alokasi Dana Desa (ADD) dilaksanakan dengan menggunakan prinsip hemat, terarah dan terkendali.

\section{Sumber Daya Manusia}

Kondisi pendidikan masyarakat akan berhubungan erat terhadap kualitas pola pikir masyarakat di dalam mengolah sumber-sumber pendapatan yang ada di daerahnya, tanpa adanya penguasaan teknologi, dan kinerja pemerintah desa yang memiliki kapabilitas, kredibilitas dan responsibilitas yang memadai.

\section{Sumber Daya Alam}

Keadaan desa yang memiliki lahan pertanian yang cukup luas dan memadai sangat mempengaruhi program pembangunan, keadaan lingkungan yang hampir terdiri dari sedikit wilayah teritorial hutan dan pepohonan kayu, menjadikan program pembangunan semakin menjadi maju dan terarah.

Tujuan dari kegiatan penyusunan Masterplan Pembangunan Desa Mandiri (MPDM) adalah merumuskan kebijakan dan kegiatan untuk pemberdayaan masyarakat (society empowerment) desa melalui: rekayasa kelembagaan (institution engineering); rekayasa sosial (social engineering) dan rekayasa sumberdaya pembangunan (resources engineering):

1. Mengidentifikasi potensi dan permasalahan dalam upaya pembangunan Desa Mandiri.

2. Merumuskan kebijakan dan melakukan kegiatan pemberdayaan masyarakat melalui rekayasa kelembagaan (institution engineering) desa untuk pembangunan Desa Mandiri.

3. Merumuskan kebijakan dan melakukan kegiatan pemberdayaan masyarakat melalui rekayasa sosial (social engineering) desa untuk pembangunan Desa Mandiri.

4. Merumuskan kebijakan dan kegiatan pemberdayaan masyarakat melalui rekayasa sumberdaya pembangunan (resources engineering) desa untuk pembangunan Desa Mandiri.

Sasaran penyusunan Masterplan Pembangunan Desa Mandiri (MPDM) adalah sebagai berikut:

1. Teridentifikasi potensi dan permasalahan desa mulai dari kelembagaan, masyarakat, sampai sumberdaya pembangunan desa.

2. Melakukan penguatan kemampuan kelembagaan Desa dalam membangun Desa Mandiri.

3. Melakukan pemberdayaan masyarakat desa dalam membangun desa Mandiri.

4. Melakukan optimalisasi potensi sumber daya Desa dalam membangun desa Mandiri. 
Manfaat penyusunan Masterplan Pembangunan Desa Mandiri (MPDM), adalah sebagai pedoman atau landasan bagi masyarakat, swasta, dan pemerintah dalam rangka pembangunan desa berdasarkan ragam potensi yang dimiliki. Selain itu MPDM ini akan memberikan rekomendasi dan referensi bagi penentu kebijakan dalam menyusun program startegis pembangunan desa, sehingga program tersebut mampu secara signifikan memberdayakan masyarakat desa sehingga akan terbangun masyarakat desa yang mandiri.

Sebagaimana telah dikemukakan, upaya pembangunan desa Mandiri dilakukan dengan pembangunan bidang ekonomi, pangan, dan energi. Bidangbidang tersebut pada dasarnya bertujuan untuk menghasilkan desa Mandiri yang memiliki kemandirian pada bidang tersebut. Setidaknya ada 5 (lima) komponen/kegiatan utama yang perlu dilakukan. Kegiatan-kegiatan tersebut meliputi:

\section{Seminar Paradigma Pembangunan Desa Mandiri}

Tujuan utama kegiatan ini adalah untuk menguraikan konsep pembangunan ekonomi dalam perspektif kemandirian ekonomi. Adapun tafsiran kemandirian ekonomi akan diuraikan dalam perspektif Ekonom Pedesaan.

\section{Identifikasi Potensi dan Permasalahan Desa}

Tujuan utama kegiatan ini adalah untuk memahami kondisi setiap desa dan kecenderungan perkembangan dalam kurun waktu perencanaan. Adapun informasi yang perlu dikumpulkan, dikaji dan dianalisis, meliputi: gambar mengenai kondisi fisik, sosial ekonomi desa/kelurahan kebijakan dan programprogram yang terkait dengan pengembangan desa, perkembangan sektor-sektor ekonomi desa dan kondisi sistem prasarana. Semua informasi ini diharapkan dapat menggambarkan eksisiting, yang tengah berlangsung (ongoing) maupun yang akan dikembangkan (commited).

Selain itu dilakukan identifikasi terhadap kondisi wilayah dan kecenderungan perkembangannya, diidentifikasi potensi ekonomi yang mampu mendukung pembangunan wilayah masing-masing desa tertinggal. Identifikasi yang dimaksud, meliputi antara lain :

- Potensi desa/kelurahan yang terkandung, baik yang sudah dimanfaatkan, belum dimanfaatkan maupun potensial diperkirakan ada di desa. Terkait dengan hal ini adalah identifikasi sektor unggulan atau komoditi unggulan.

- Kendala-kendala dalam pengembangan potensi ekonomi, baik dalam kaitannya dengan bidang prasarana, keuangan dan kebijakan.

3. Pelaksanaan Program dan Kegiatan Pembangunan Desa Mandiri

Program dan Kegiatan pembangunan desa Mandiri meliputi tiga program yaitu: pemberdayaan masyarakat melalui rekayasa kelembagaan (institution engineering) desa, pemberdayaan masyarakat melalui rekayasa sosial (social engineering) desa, pemberdayaan masyarakat melalui rekayasa sumberdaya pembangunan (resources engineering) desa.

Pemberdayaan masyarakat melalui rekayasa kelembagaan (institution engineering) desa meliputi:
a. Program
peningkatan
kemampuan dasar aparatur desa, meliputi: pengetahuan tentang regulasi desa, pengetahuan tentang dasar-dasar pemerintahan desa, dan pengetahuan tentang tugas pokok dan fungsi.
b. Program peningkatan kemampuan manajemen aparatur


desa, meliputi: Manajemen SDM, manajemen pelayanan publik, manajemen aset, dan manajemen keuangan.

c. Program kerja peningkatan kemampuan teknis aparatur desa, meliputi antara lain: Penyusunan administrasi desa, Penyusunan perencanaan pembangunan desa, penyusunan anggaran belanja desa, penyusunan peraturan, dan pelayanan publik.

Pemberdayaan masyarakat melalui rekayasa sosial (social engineering) desa meliputi:

a. Program peningkatan kemampuan pemberdayaan masyarakat Mandiri, meliputi: Optimalisasi peran masjid dalam pembangunan desa, optimalisasi dana ZISWAF (Zakat, Infaq, Shodaqoh, dan Wakaf).

b. Program peningkatan kemampuan kreativitas dan inovasi, meliputi: pemanfaatan teknologi informasi, energi alternatif, diversifikasi pangan, dan solid waste management.

Pemberdayaan masyarakat
melalui rekayasa rumberdaya
pembangunan (resources
dengineering)
desa meliputi:

a. Progam peningkatan pendidikan masyarakat, meliputi: gerakan bebas buta aksara pedesaan, gerakan literasi pendidikan, serta pendirian taman baca masyarakat.

b. Program peningkatan kesehatan masyarakat, meliputi: penyuluhan gizi, pemeriksaan kesehatan, gerakan lingkungan bersih dan sehat, serta gerakan peduli kesehatan.

c. Program peningkatan ekonomi masyarakat, meliputi: pelatihan manajemen keuangan keluarga, pelatihan kewirausahaan, pemberian bantuan bibit, dan pelatihan olahan hasil pertanian dan perikanan.

4. Perumusan Model Pembangunan Desa Mandiri

Rumusan model Pembangunan Desa Mandiri yang dimaksud berisi program-program pengembangan sektor, desa dan sistem prasarana dasar. Program-program ini dirumuskan dalam rangka mendukung pencapaian skenario-skenario yang telah dirumuskan.

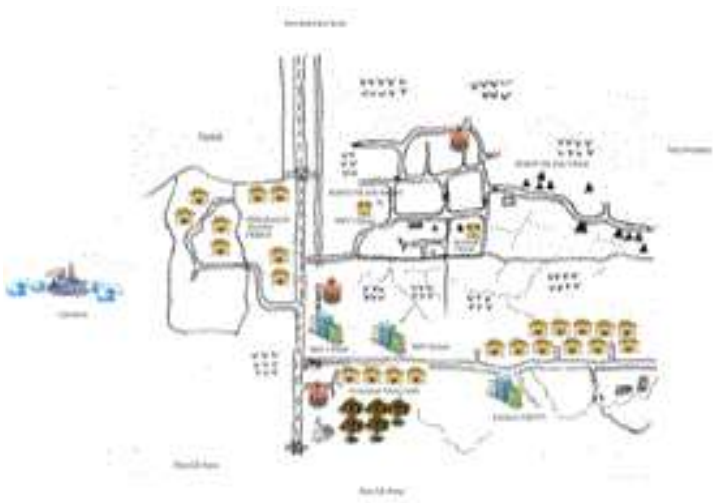

Gambar 4. Peta Desa Laboratorium

5. Rekomendasi Pola Pelaksanaan Program-Program Pembangunan Desa Mandiri

Program-program yang layak untuk diimplementasikan, selanjutnya dikaji pola pelaksanaannya. Dalam hal ini pola pelaksanaan yang dimaksud memperhitungkan seluruh pelaku pembangunan, yaitu pemerintah, swasta dan masyarakat.

Sebagai objek dari kegiatan ini, maka dipilih desa-desa yang lokasinya berdekatan dengan lokasi kampus Universitas Trunojoyo Madura yaitu: (1) Desa Telang, (2) Desa Pendabah, (3) Desa Kamal dan (4) Desa Gili Anyar pada tahun pertama kegiatan. Jumlah desa yang 
dijadikan sebagai objek kegiatan akan terus bertambah pada tahun-tahun berikutnya.

Beberapa program unggulan dikemas dalam kegiatan yang bersifat rutin dan di evaluasi tingkat pelaksanannya secara kontinyu. Salah satu program yang berhasil diwujudkan dalam tahun 2019 adalah layanan desa berbasis web yang terinspirasi dari e-commerce yang ada dalam dunia bisnis (Evasari, Utomo, \& Ambarwati, 2019).

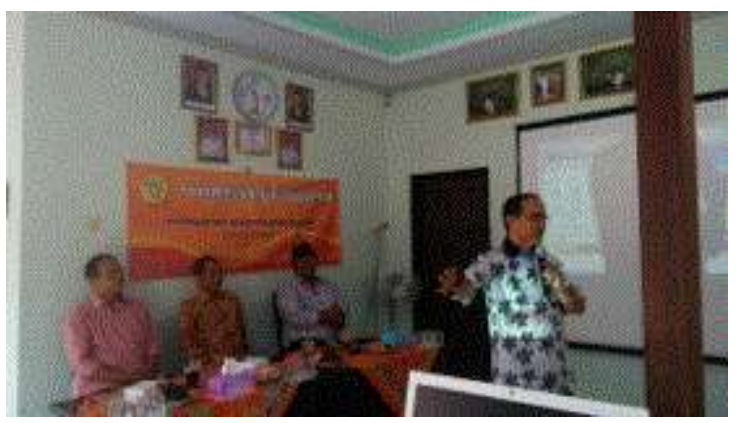

Gambar 5. Launching Layanan Web Desa

Gambar 5 diatas menunjukkan salah satu rangkaian dari kegiatan penguatan desa binaan sekitar kampus yang dilaksanakan di salah satu desa, yakni Desa Gili Anyar. Berdasarkan kegiatan pengandian dari tahun sebelumnya diperoleh temuan bahwa salah satu keluhan masyarakat desa adalah kecepatan layanan desa untuk mengurus surat-surat keterangan lahir, kependudukan serta surat lain yang terkait. Melalui program pengadaan layanan desa berbasis web ini diharapkan banyak layanan masyarakat yang bisa dilakukan secara lebih cepat dan akurat.

Secara umum, berdasarkan hasil monitoring dan evaluasi program laboratorium desa pada tahun pertama, dapat dikatakan bahwa efek yang paling terasa dari program ini adalah munculnya rasa optimisme masyarakat desa untuk bisa mencapai tujuan pembangunan desa secara lebih baik. Proses pembangunan ini semakin diperkuat dengan tingkat partisipasi masyarakat yang semakin tinggi.

\section{Penutup}

\section{Simpulan}

Kegiatan pengabdian masyarakat yang dikemas dalam program laboratorium desa ini dimotivasi oleh adanya kenyataan bahwa kondisi desa sekitar kampus yang relatif tertinggal. Padahal kampus diharapkan memberikan kontribusi nyata terhadap masyarakat sekitar sebagai prioritas kegiatan Tri Dharma Perguruan Tinggi. Sebagai realisasi program ini maka di tahun pertama dilakukan sub-program One Class One Villages (OCOV) yang ternyata memiliki respons cukup positif dari masyarakat desa.

Bentuk respons positif adalah berupa permohonan dari masyarakat desa untuk melaksanakan program tertentu guna meningkatkan layanan masyarakat. Dengan demikian telah muncul kesadaran masyarakat setempat akan pentingnya pembangunan desa. Saat ini mahasiswa yang diterjunkan ke desa relatif terbatas mengingat terbatasnya jadwal dan persiapan. Kelak, kegiatan ini dapat diperluas dengan melibatkan persiapan yang lebih matang.

\section{Saran}

Meskipun terintegrasi dengan kurikulum, namun waktu pelaksanaan pengabdian di desa harus menyesuaikan dengan jadwal kuliah sehingga banyak kegiatan yang belum bisa diselesaikan secara optimal. Di sisi lain, peran dosen pendamping dalam memberikan masukan masih cukup dominan, padahal diharapkan mahasiswa bersama masyarakat setempat yang memiliki inisiatif dalam menentukan, melaksanakan dan mengevaluasi program kerja.

\section{Ucapan Terima Kasih}

Ucapan terima kasih penulis sampaikan kepada pihak yang terlibat aktif dalam program laboratorium desa Jurusan Ilmu Ekonomi FEB UTM terutama para kades yang telah banyak membantu suksesnya program ini. 


\section{Daftar Pustaka}

Evasari, A. D., Utomo, Y. B., \& Ambarwati, D. (2019). Pelatihan dan Pemanfaatan E-Commerce Sebagai Media Pemasaran Produk UMKM di Desa Tales Kecamatan Ngdiluwih Kabupaten Kediri. Cendekia: Jurnal Pengabdian Masyarakat, 75-84.

Harmalik, O. (2001). Pengembangan Sumber Daya Manusia Manajemen Pelatihan Ketenagakerjaan: Pendekatan Terpadu. Jakarta: Bumi Aksara.

Mulyanto, D. (2011). Ekonomi Pekarangan di Pedesaan Jawa. Jurnal Komunitas, 3(1), 19-28.

Samidjo, G. S. (2016). Pengembangan Desa Wisata Belajar Berbasis Potensi Alam dan Pertanian di Polengan, Srumbung, Magelang. Jurnal Berdikari, 44-53.

Sukayadi, Indradi, Wiyono, Subroto, \& Nugroho. (2013). Pengembangan Desa dan Rintisan Pengembangan Laboratorium Desa STPN Melalui Penyusunan Profil Desa. Yogyakarta: Pusat Penelitian dan Pengabdian Kepada Masyarakat Sekolah Tinggi Pertanahan Nasional.

Suripan, Sucipto, Nurhadi, \& Sopingi. (2017). Pendampingan Penyusunan Program Pengembangan Desa Laboratorium. Abdimas Pedagogi, 87-93. 